\title{
Bioremediation of Southern Mediterranean oil polluted sites comes of age
}

Daniele Daffonchio ${ }^{1 *}$, Manuel Ferrer ${ }^{2}$, Francesca Mapelli ${ }^{1}$, Ameur Cherif ${ }^{3}$, Álvaro Lafraya ${ }^{2}$, Hanan I. Malkawi ${ }^{4}$, Michail M. Yakimov ${ }^{5}$, Yasser R. Abdel-Fattah ${ }^{6}$, Mohamed Blaghen ${ }^{7}$, Peter N. Golyshin $^{8}$, Nicolas Kalogerakis ${ }^{9}$, Nico Boon ${ }^{10}$, Mirko Magagnini ${ }^{11}$, Fabio Fava ${ }^{12}$

${ }^{1}$ Department of Food Science and Microbiology, University of Milan, Milan, Italy;

${ }^{2}$ Institute of Catalysis, Consejo Superior de Investigaciones Científicas, Madrid, Spain;

${ }^{3}$ Laboratory of Microorganisms and Active Biomolecules, University of Tunis El Manar, Tunis, Tunisia and Laboratory BVBGR, LR11ES31, Biotechnology Institute, University of Manouba;

${ }^{4}$ Department of Biological Sciences, Yarmouk University, Irbid, Jordan;

${ }^{5}$ Institute for Coastal Marine Environment, Consiglio Nazionale delle Ricerche, Messina, Italy;

${ }^{6}$ Genetic Engineering and Biotechnology Research Institute, City for Scientific Research \& Technology Applications, Alexandria, Egypt;

${ }^{7}$ Laboratory of Microbiology, Biotechnology and Environment, University Hassan II - Ain Chock, Casablanca, Morocco;

${ }^{8}$ School of Biological Sciences, Bangor University, Bangor, UK;

${ }^{9}$ Department of Environmental Engineering Technical University of Crete, Chania, Greece;

${ }^{10}$ Laboratory of Microbial Ecology and Technology (LabMET), Ghent University, Gent, Belgium;

${ }^{11}$ EcoTechSystems L.t.d, Ancona, Italy;

${ }^{12}$ Department of Civil, Environmental and Materials Engineering, University of Bologna, Bologna, Italy.

\section{*Author for correspondence:}

Daniele Daffonchio, DeFENS, University of Milan, via Celoria 2, 20133, Milan Italy. Tel: +390250319117; Fax: +39-0250319238; E-mail: daniele.daffonchio@unimi.it 


\begin{abstract}
Mediterranean Sea is facing a very high risk of oil pollution due to the high number of oil extractive and refining sites along the basin coasts, and the intense maritime traffic of oil tankers. All the Mediterranean countries have adopted severe regulations for minimizing pollution events and bioremediation feasibility studies for the most urgent polluted sites are undergoing. However, the analysis of the scientific studies applying modern 'meta-omics' technologies that have been performed on marine oil pollution worldwide showed that the Southern Mediterranean side has been neglected by the international research. Most of the studies in the Mediterranean Sea have been done in polluted sites of the Northern side of the basin. Those of the Southern side are poorly studied, despite many of the Southern countries being major oil producers and exporters. The recently EU-funded research project ULIXES (http://www.ulixes.unimi.it/) has as a major objective to increase the knowledge of the bioremediation potential of sites from the Southern Mediterranean countries. ULIXES is targeting four major polluted sites on the coastlines of Egypt, Jordan, Morocco and Tunisia, including seashore sands, lagoons, and oil refinery polluted sediments. The research is designed to unravel, categorize, catalogue, exploit and manage the diversity and ecology of microorganisms thriving in these polluted sites. Isolation of novel hydrocarbon degrading microbes coupled with a series of state of the art 'meta-omics' technologies are the baseline tools for improving our knowledge on biodegradation capacities mediated by microbes under different environmental settings and for designing novel site-tailored bioremediation approaches. A network of twelve European and Southern Mediterranean partners is cooperating for plugging the existing gap of knowledge for the development of novel bioremediation processes targeting such poorly investigated polluted sites.
\end{abstract}

Keywords:

Southern Mediterranean Countries; oil-polluted sites; marine microbial ecology; metagenomics; metaproteomics

\title{
1. Introduction
}

In the last centuries the marine environments worldwide faced a constantly increasing pollution load due to the strong development of the extractive and transformation industry, the goods transportation and the increase of the coastal population. Such a pollution load is affecting the marine environmental preservation worldwide, and especially in those areas of closed basins with slow water turnover. The Mediterranean Sea is one of the world semi-enclosed basins at high risk of pollution considering the increase of the population on all the coasts, the strong maritime traffic and the oil extractive and refining industries present all around the basin coasts [1]. The numbers of potential hot spots for oil pollution in the Mediterranean Sea are impressive with around tens oil-related sites on the Mediterranean coastal zone including pipeline terminals, oil refineries and offshore platforms. Several of the countries facing on the Mediterranean Sea, especially on the Southern side are major oil and gas producers and the oil terminals located on their shore lines represent major pollution hot spots. The countries on the Northern side of the basin are major oil importers and have installed a series of oil refinery terminals that receive oil and gas from their Southern counterparts. Further potential pollution sources are the oil and gas pipelines connecting the two sides of the basin and the intensive offshore oil drilling and extracting activities which are undergoing an increasing trend [2].

The intense maritime traffic was estimated as about 55,000,000 metric tons of crude oil transferred within the Mediterranean Sea every year, making the basin at high risk of pollution. Indeed, many accidents occurred in the last decades, including pipeline breaks and shipwrecks of oil tankers like, for instance, among many others, the Haven tanker sunk in the Gulf of Genoa in

1991(http://en.wikipedia.org/wiki/MT_HAVEN") and the Patmos and the Agip Abruzzo oil spills, respectively occurred in Calabria on 1985 and in the Ligurian Sea on 1991 [3], or the oil spill occurred from the Iliad tanker on the Greek coast on 1993 [4] and the leakage of fuel oil from the Eshkol power station in Israel on 1998 [5]. These dramatic pollution events strongly affected the coastline of the involved Mediterranean countries. In respect to many other industrialized areas in the world, the ratio between the oil tanker traffic and the surface area of the basin is strongly unbalanced towards the former. The oil tanker traffic in the Mediterranean Sea represents more than $20 \%$ of the global traffic even though the Mediterranean Sea size represent just the $1 \%$ of the total marine surface of our planet. This is a key aspect to be taken into account while investigating the oil pollution phenomena in the Mediterranean Sea given that different reports indicated the 
deliberate oil release from the ship during routine operations, such as deballasting and tank washing, as a major threat affecting the Mediterranean Sea ecosystem [6; 7].

Many sites of the Mediterranean basin are already polluted including coastal lagoons and lakes, harbor areas and river estuaries [8]. These include very delicate ecosystems, like for instance the Bizerte lagoon in the lake system of the Ichkeul National Park in Tunisia [9], or important historical areas like the Venice lagoon in the Mestre industrial sites in Italy [10; 11].

The countries on the Mediterranean Sea have adopted severe regulations for minimizing pollution events and the assessment of bioremediation procedure feasibility for the most urgent polluted sites are undergoing.

Powerful sequencing technologies are nowadays widely applied to investigate the microbiology of oil polluted sites worldwide, nonetheless a survey of the available studies published in the last two years [12-37] indicates that oil pollution sources in the sites of the Southern side of the Mediterranean basin are only poorly studied (Figure 1).

Most of these sites would benefit of the research community efforts for identifying the suitable microbial resources for developing adequate and sustainable clean-up strategies.

The EU project ULIXES ("Unravelling and exploiting Mediterranean Sea microbial diversity and ecology for xenobiotics' and pollutants' clean up) has been designed in this framework for responding to this knowledge gap by exploiting a North-South and East-West Mediterranean and European research cooperation.

\section{The Southern Mediterranean polluted sites studied under ULIXES}

The recent political events in the Arab countries facing the Southern side of the Mediterranean Sea marked a turning point towards the integration of the social, economic and cultural activities between the south and north sides of the basin [38]. The new course is expected to favor the flourishing of a virtuous integration of science and research between the countries on the Southern side of the Mediterranean basin and the rest of the world including Europe [39]. The project ULIXES is in line with this new course since it integrates the collaboration between eight laboratories from the European Union and four laboratories from Egypt, Jordan, Morocco and Tunisia.

ULIXES is targeting among others four sites from these countries polluted with oil hydrocarbons. In Egypt, the site of El-Max district and its shore are located in the western side of the city of Alexandria. In the past, it was one major place for fishing, where the fresh water coming from Mahmoudyah panel flows into the sea water of the El-Max shore. In addition, large numbers of holidaymakers used to enjoy swimming and water playing in this district. In the last three decades many chemical, tannery and petroleum industries started to take place in this region which threatened the shores with dangers of contamination with petroleum oil spills coming from a nearby gas plant. This area is the most contaminated sea shore in the Alexandria region and exceeds legal environmental pollution limits for heavy metals, polycyclic aromatic hydrocarbons (PAHs) and crude oil-derived pollutants.

In Jordan the Gulf of Aqaba, located at the northern end of the Red Sea, is the northernmost tropical sea ecosystem. The Gulf supports a dense population of more than 150 species of corals, 500 species of fish and thousands of other species of crustaceans and mollusks in a fragile environmental equilibrium. The Gulf of Aqaba, despite not being on the Mediterranean Sea is an interesting model for the future of the basin according to the continuation of the actual global warming trend. The region's delicate ecosystem, which is the main source of attraction in the area, is at the same time endangered by uncontrolled development. Conveyance installations for oil and phosphates as well as other industrial activities together with the oil terminals of the Eilat and Aqaba harbors (Aqaba port alone handles between 20-30 million tons yearly) are major sources of pollution [40].

The lagoon of Mar Chica is located in the north-west Mediterranean coast of Morocco facing the Alboran Sea between the cities of Beni Enzar and Kariat Arkmane. It is a 112 square kilometers lagoon isolated from the Mediterranean by a thin sand cord and dunes, but has a channel of communication with the sea through the master key of Boucana. Among the largest lagoons in the south coast of the Mediterranean Sea, Mar Chica is dominated by the mountains of Rif and has a depth varying between a half-meter and seven meters. Despite Mar Chica is of biological, ecological and landscape interest it is exposed to continuous pollution by the town of Nador, located on its south-western shore. The lagoon suffers depletion of oxygen that determined the fish 
disappearance. Several uncontrolled sewers and landfills affect the lagoon. Pollution comes from the city itself, but also from agriculture and industries that discharge pollutants in the lagoon.

A Tunisian site studied in ULIXES is the Bizerte lagoon which represents a buffer zone between inland freshwater lakes and the marine environment. The 150 square kilometers lagoon is located in the Northern Tunisia and connects the Mediterranean Sea and the Ichkeul Lake. The Lake Ichkeul is a part of an important Natural Park in Tunisia and receives in summer the salty water of the Bizerte lagoon. The lagoon is highly populated and urbanized, and is subjected to environmental pollution by sewage, industrial and aquaculture waste, agricultural run-offs and other human activities. Moreover, the most important oil refinery in Tunisia (STIR, Société Tunisienne des Industries de Raffinage) is located close to the Jarzouna channel, which connects the Bizerte lagoon to the Mediterranean Sea. The lagoon pollution load is determined by petroleum components in the area adjacent to the STIR refinery. Recent studies have monitored contaminations of non-aromatic, aromatic and polycyclic aromatic hydrocarbons as well as heavy metals [9].

In the following paragraph the strategies designed by ULIXES for assessing and exploiting the microbial biodiversity associated to the above sites in the Southern Mediterranean are described, integrating microbiology, microbial ecology analyses, 'omics' technologies and experimental designs to test bioremediation approaches.

\section{The ULIXES approach for discovering novel microbial resources for bioremediation}

The final objective of the overall studies in the four Southern Mediterranean sites, and possible other future sites to be considered, is to assess the diversity and functionality of the microbial communities inhabiting the polluted sites in relation to the potential of cleaning up the polluted matrices. Moreover, the project aims to test the best microbial resources in mesocosms and semifield experiments.

In phase 1 the research teams located in the countries of the identified Southern Mediterranean polluted sites perform the sampling of water sediments, soil and sands (Figure 2).

In the second phase of the project a number of teams work at the isolation of microbes and microbial consortia capable of oil hydrocarbons degradation or of producing biosurfactants, important elements produce by microbes to improve hydrocarbon solubility (Figure 2). This is accomplished not only for the Sothern Mediterranean sites but for all the other sampled environments in the ambit of ULIXES $[32 ; 42]$. The research activities will be also targeting the selection of strains capable of producing extracellular enzymes, polysaccharides and to form biofilms. Some of the teams concentrate the efforts on the selection of microbes capable of degrading other pollutants like chlorinated aliphatic solvents and polychlorobyphenils (PCBs) by means of reductive dechlorination [43]. Strains capable of bioprecipitating biopalladium nanoparticles are also target of the isolation effort. Biopalladium nanoparticles are interesting catalyzers of the degradation for instance of chlorinated compounds [44; 45]. All the isolates and the mixed consortia are categorized, catalogued and stored in microbial collections available at the laboratories of the partners.

The structure and diversity of the microbial communities associated to the different sites and their ecological features are assessed by some of the teams using established molecular ecology techniques and advanced metagenomic approaches like barcoding coupled to pyrosequencing of molecular chronometers (Figure 2). An example of this approach is the study by Gertler et al. [35] done on ULIXES samples other than those from the Southern Mediterranean sites. For assessing the function of the microbial communities, besides activity and standard physiological measures, some of the teams of ULIXES use 'omics' techniques for defining a metabolic map of microbial communities active in the polluted sites and for retrieving novel enzymes and metabolites involved in linear and polycyclic aromatic hydrocarbons degradation independently from the microbe cultivation. An example of this approach is the study by Guazzaroni et al. [46] done on samples other than those from the Mediterranean sites. Following genomics of interesting isolates and metagenomics of oil degrading consortia enzymes of interest are selected by genome gazing and by the way of high throughput screening tools and the interesting genes are cloned and selected. In parallel, by working at the protein level proteomic and metabolomic approaches are used for high throughput identification of multiple enzymes in arrayed reactions.

These efforts produce a series of collections of microorganisms or enzyme clones that can be used for the design of improved and site-tailored bioremediation processes (Figure 2). Special attentions are given towards the production of novel oil degrading enzymes and biosurfactants, the 
optimization of reductive dehalogenation processes in minireactor systems for the dechlorination of PCBs and chlorinated solvents like 1,2-dichloroethane and the processes based on biopalladium nanoparticles [47; 48].

In the third phase of the activities treatment attempts are performed in the Egyptian and Jordan sites on on-site mesocosms designed for simulating the conditions occurring in situ in the two polluted sites (Figure 2). These experiments are complemented by parallel experiments conducted in microcosms in the laboratories. For the mesocosm experiments the best microbial consortia are selected basing on the results of the microcosm experiments.

It is expected that ULIXES will produce a detailed set of information on the microbiology of the selected polluted sites in the Southern side of the Mediterranean Sea, contributing to filling the actual knowledge gap in these polluted sites.

\section{The ULIXES Consortium}

ULIXES is a small to medium scale collaborative EU FP7 project for Specific Cooperation Actions Dedicated to International Cooperation (CP-FP-SICA) in the theme of Food, agriculture and fisheries and biotechnology in the area of Environmental Biotechnology. The project is coordinated by the University of Milan in Italy. The project started in February 2011 and lasts for 36 months.

Twelve partners from five countries in Europe and four countries on the Southern coast of the Mediterranean Sea are contributing to the development of ULIXES:

1. Partner 1, UMIL, University of Milan, Italy: Project coordination; microbial ecology of polluted sites; screening of consortia with reductive dechlorination capabilities.

2. Partner 2, UTUN, University of Tunis El Manar, Tunisia: Collection establishment of pollutant microbial degraders; microbial ecology of polluted sites; screening and testing new strains; coordination of dissemination activities.

3. Patner 3, YU, Yarmouk University, Jordan: Sampling from contaminated sites at the Gulf of Aqaba; isolation of HC degrading microbes; scaling up of $\mathrm{HC}$ degrading cultures; laboratory and in-situ pilot experiment.

4. Partner 4, IAMC, Consiglio Nazionale delle Ricerche, Italy: Organization of cruises and sampling coordination; phylogenetic survey of prokaryotic communities; monitoring expression of biodegradation key-enzymes; large-scale mesocosm experiments.

5. Partner 5, MUCSAT, City for Scientific Research \& Technology Applications, Egypt: Sampling from Egypt contaminated sites; isolation of degrading microbes; numerical modelling of microbial consortia; optimization of bioremediation inocula in bioreactors; in-situ pilot experiments of the produced consortia.

6. Partner 6, UH2C, Universitè Hassan II Ain Chock Casablanca, Morocco: Sampling from contaminated sites in Morocco; microbial diversity analysis; isolation of degrading microbes, development of HC-degrading consortia.

7. Partner 7, BANGOR, Bangor University, United Kingdom: Establishment of metagenomic and expression libraries; metagenomics; identification of relevant enzymatic processes; Cloning of different HC-related enzymes.

8. Partner 8, CSIC, Agencia Estatal Consejo Superior de Investigaciones Cientificas, Spain: Construction of a metabolic atlas of polluted samples; annotations of hypothetical genes, Characterization of biodegradation enzymes.

9. Partner 9, TUC, Technical University of Crete, Greece: Sampling from contaminated sites in Greece; enrichment of biosurfactant- biofilm-producing microbes; testing new product/processes by microcosms, mesocosms and pilot field tests.

10. Partner 10, UGENT, Ghent University, Belgium: Isolation of biopalladium (bio-pd) nanoparticles precipitating microbes; novel dechlorination processes catalyzed by bio-pd nanoparticles.

11. Partner 11, ETS, EcoTechSystem srl, Italy: Sediment sampling in Ancona harbor; physical and chemical characterization of sediments; measure of total prokaryotic abundance, biomass and diversity; assessment of metal and metalloids mobilization in sediments.

12. Partner 12, UNIBO, Alma Mater Studiorum-Università di Bologna, Italy: Sampling Venice Lagoon polluted sediments; study of PCB-dechlorinating processes; Characterization of biosurfactant productivity and strain ecotoxicology; bioaugmentation experiments for lab-scale PCB dechlorination.

Further details on ULIXES can be found at http://www.ulixes.unimi.it/. 


\section{References}

[1] Daffonchio D, Mapelli F, Cherif A, Malkawi HI, Yakimov MM, Abdel-Fattah YR, Blaghen M, Golyshin PN, Ferrer M, Kalogerakis N, Boon N, Magagnini M, Fava F (2012) ULIXES, unravelling and exploiting Mediterranean Sea microbial diversity and ecology for xenobiotics' and pollutants' clean up. Rev Environ Sci Biotechnol 11:207-211.

[2] Margottini L (2012) Gulf drilling disaster triggers scrutiny of Mediterranean oil rush. Science 333:285.

[3] Danovaro R (2003): Pollution threats in the Mediterranean Sea: An overview. Chemistry and Ecology, 19: 15-32.

[4] Koutsoubas D, Dounas C, Arvanitidis C, Kornilios S, Petihakis G, Triantafyllou G, Eleftheriou A (2000) Macrobenthic community structure and disturbance assessment in Gialova Lagoon, Ionian Sea. ICES Journal of Marine Science, 57: 1472-1480.

[5] Ezra S. Feinstein S, Pelly I, Bauman D, Miloslavsky I (2000) Weathering of fuel oil spill on the east Mediterranean coast, Ashdod, Israel. Organic Geochemistry 31: 1733-1741

[6] Abdulla A, Linden O (2008) Maritime traffic effects on biodiversity in the Mediterranean Sea: Review of impacts, priority areas and mitigation measures. Malaga, Spain: IUCN Centre for Mediterranean Cooperation. 184 pp.

[7] Pavlakis P, Tarchi D, Sieber AJ (2001) On the monitoring of illicit vessel discharges, a reconnaissance study in the Mediterranean Sea. Annales Des Télécommunications,Vol. 56, Issue 11-12, pp 700-718

[8] UNEP/WHO (1999) Identification of priority pollution hot spots and sensitive areas in the Mediterranean. MAP Technical Reports Series, No.124, UNEP, Athens.

[9] Zrafi-Nouira I, Khedir-Ghenim Z, Bahri R, Cheraeif I, Rouabhia M, Saidane-Mosbahi D (2009) Hydrocarbons in seawater and water extract of Jarzouna-Bizerte coastal of Tunisia (Mediterranean Sea): Petroleum origin investigation around refinery rejection place. Water Air Soil Poll 202:19-31.

[10] Zanaroli G, Balloi A, Negroni A, Daffonchio D, Young LY, Fava F (2010) Characterization of the microbial community from the marine sediment of the Venice lagoon capable of reductive dechlorination of coplanar polychlorinated biphenyls (PCBs). J Hazard Mat 178:417-426.

[11] Borin S, Brusetti L, Daffonchio D, Delaney E, Bald F (2009) Biodiversity of prokaryotic communities in sediments of different sub-basins of the Venice lagoon. Res Microbiol 160: 307314.

[12] Ivanišević J, Thomas OP, Lejeusne C, Chevaldonné P, Pérez T (2011) Metabolic fingerprinting as an indicator of biodiversity: Towards understanding inter-specific relationships among homoscleromorpha sponges. Metabolomics 7: 289-304.

[13] Ghai R, Hernandez CM, Picazo A, Mizuno CM, Ininbergs K, Díez B, Valas R, Dupont CL, Mcmahon KD, Camacho A, Rodriguez-Valera F (2012) Metagenomes of mediterranean coastal lagoons. Scientific Reports 2.

[14] Santos F, Moreno-Paz M, Meseguer I, Lopez C, Rossello-Mora R, Parro V, Anton J (2011) Metatranscriptomic analysis of extremely halophilic viral communities. ISME J 5: 1621-1633.

[15] Cantalupo PG, Calgua B, Zhao G, Hundesa A, Wier AD, Katz JP, Grabe M, Hendrix RW, Girones R, Wang D, Pipas JM (2011) Raw sewage harbors diverse viral populations. MBio 2.

[16] Cretoiu MS, Kielak AM, Abu Al-Soud W, Sorensen SJ, Van Elsas JD (2012) Mining of unexplored habitats for novel chitinases--chiA as a helper gene proxy in metagenomics. Appl Microbiol Biotechnol 94: 1347-1358.

[17] Bayer K, Scheuermayer M, Fieseler L, Hentschel U (2013) Genomic mining for novel fadh2dependent halogenases in marine sponge-associated microbial consortia. Marine Biotechnology 15: 63-72.

[18] Ardura A, Planes S, Garcia-Vazquez E (2011) Beyond biodiversity: Fish metagenomes. PLoS ONE 6.

[19] Jean N, Dumont E, Durrieu G, Balliau T, Jamet JL, Personnic S, Garnier C (2012) Protein expression from zooplankton communities in a metal contaminated nw mediterranean coastal ecosystem. Marine Environmental Research 80: 12-26.

[20] Kisand V, Valente A, Lahm A, Tanet G, Lettieri T (2012) Phylogenetic and functional metagenomic profiling for assessing microbial biodiversity in environmental monitoring. PLoS ONE 7.

[21] Picone G, Engelsen SB, Savorani F, Testi S, Badiani A, Capozzi F (2011) Metabolomics as a powerful tool for molecular quality assessment of the fish sparus aurata. Nutrients 3: 212-227. 
[22] Brochier-Armanet C, Deschamps P, López-García P, Zivanovic Y, Rodríguez-Valera F, Moreira D (2011) Complete-fosmid and fosmid-end sequences reveal frequent horizontal gene transfers in marine uncultured planktonic archaea. ISME Journal 5: 1291-1302.

[23] López-Pérez M, Gonzaga A, Martin-Cuadrado AB, López-García P, Rodriguez-Valera F, Kimes, NE (2012) Intra- and intergenomic variation of ribosomal rna operons in concurrent Alteromonas macleodii strains. Microbial Ecology: 1-11.

[24] Hütz A, Schubert K, Overmann J (2011) Thalassospira sp. Isolated from the oligotrophic eastern mediterranean sea exhibits chemotaxis toward inorganic phosphate during starvation. Appl. Environ. Microbiol. 77: 4412-4421.

[25] Thompson AW, Huang K, Saito MA, Chisholm SW (2011) Transcriptome response of highand low-light-adapted prochlorococcus strains to changing iron availability. ISME J 5: 1580-1594.

[26] Smedile F, Messina E, La Cono V, Tsoy O, Monticelli LS, Borghini M, Giuliano L, Golyshin PN, Mushegian A, Yakimov MM (2013) Metagenomic analysis of hadopelagic microbial assemblages thriving at the deepest part of mediterranean sea, matapan-vavilov deep. Environ. Microbiol. 15: 167-182.

[27] Ferrer M, Werner J, Chernikova TN, Bargiela R, Fernández L, La Cono V, Waldmann J, Teeling H, Golyshina OV, Glöckner FO, Yakimov, MM, Golyshin PN (2012) Unveiling microbial life in the new deep-sea hypersaline lake thetis. Part ii: A metagenomic study. Environmental Microbiology 14: 268-281.

[28] Quaiser A, Zivanovic Y, Moreira D, López-García P. (2011) Comparative metagenomics of bathypelagic plankton and bottom sediment from the sea of marmara. ISME J 5: 285-304.

[29] Zurel D, Benayahu Y, Or A, Kovacs A, Gophna U (2011). Composition and dynamics of the gill microbiota of an invasive indo-pacific oyster in the eastern mediterranean sea. Environ. Microbiol.13: 1467-1476.

[30] Elsaied H, Stokes HW, Kitamura K, Kurusu Y, Kamagata Y, Maruyama A (2011) Marine integrons containing novel integrase genes, attachment sites, atti, and associated gene cassettes in polluted sediments from suez and tokyo bays. ISME J 5: 1162-1177.

[31] Wang L, Chen S, Vergin KL, Giovannoni SJ, Chan SW, Demott MS, Taghizadeh K, Cordero OX, Cutler M, Timberlake S, Alm EJ, Polz MF, Pinhassi J, Deng Z, Dedon PC (2011) DNA phosphorothioation is widespread and quantized in bacterial genomes. PNAS 108: 2963-2968.

[32] Cappello S, Crisari A, Denaro R, Crescenzi F, Porcelli F, Yakimov MM (2011) Biodegradation of a bioemulsificant exopolysaccharide (eps2003) by marine bacteria. Water, Air, and Soil Pollution 214: 645-652.

[33] Cappello S, Crisari A, Hassanshahian M, Genovese M, Santisi S, Yakimov MM (2012) Effect of a bioemulsificant exopolysaccharide (eps 2003) on abundance and vitality of marine bacteria. Water, Air, and Soil Pollution 223: 3903-3909.

[34] Cappello S, Genovese M, Della Torre C, Crisari A, Hassanshahian M, Santisi S, Calogero R, Yakimov MM (2012) Effect of bioemulsificant exopolysaccharide (eps 2003) on microbial community dynamics during assays of oil spill bioremediation: A microcosm study. Mar Pollut Bull 64: 2820-2828.

[35] Gertler C, Näther DJ, Cappello S, Gerdts G, Quilliam RS, Yakimov MM, Golyshin PN (2012) Composition and dynamics of biostimulated indigenous oil-degrading microbial consortia from the Irish, North and Mediterranean Seas: a mesocosm study. FEMS Microbiol Ecol 81:520536.

[36] Cappello S, Russo D, Santisi S, Calogero R, Gertler C, Crisafi F, De Domenico M, Yakimov MM (2012) Presence of hydrocarbon-degrading bacteria in the gills of mussel Mytilus galloprovincialis in a contaminated environment: A mesoscale simulation study. Chemistry and Ecology 28: 239-252.

[37] Mancini G, Cappello S, Yakimov MM, Polizzi A, Torregrossa M (2012) Biological approaches to the treatment of saline oily waste(waters) originated from marine transportation. Chemical Engineering Transactions 27: 37-42.

[38] Butler D (2011) Tunisian scientists rejoice at freedom. Nature 469:453-454.

[39] Fathallah MD (2012) Arab science to turn spring into summer. Nature 480:39.

[40] Rasheed M, Al Najjar T, Al-Masri MG, Mian S (2011) Experimental degradation of oil in permeable sand from the Gulf of Aqaba, Red Sea. Chem Ecol 27:287-295.

[41] Cappello S, Santisi S, Calogero S, Hassnshahian M, Yakimov MM (2012) Characterisation of oil-degrading bacteria isolated from bilge water. Water Air Soil Pollut 223:3219-3226.

[42] Mahjoubi M, Jaouan A, Guesmi A, Ben Amor S, Jouini A, Cherif H, Najjari A, Boudabous A, Koubaa N, Cherif A (2013) Hydrocarbonoclastic bacteria isolated from petroleum contaminated sites in Tunisia: isolation, identification and characterization of the biotechnological potential. New Biotech, In press. 
[43] Zanaroli G, Balloi A, Negroni A, Borruso L, Daffonchio D, Fava F (2012) A Chloroflexi bacterium dechlorinates polychlorinated biphenyls in marine sediments under in situ-like biogeochemical conditions. J Hazard Mat 209:449-457.

[44] Hennebel T, De Corte S, Verstraete W, Boon N (2012) Microbial production and environmental applications of Pd nanoparticles for treatment of halogenated compounds. Curr Opin Biotech. 23:1-7.

[45] De Corte S, Hennebel T, De Gusseme B, Verstraete W, Boon N (2011) Bio-palladium: from metal recovery to catalytic applications. Microbial Biotechnol 5:5-17.

[46] Guazzaroni M-E, Herbst F-A, Lores I, Tamames J, Peláez AI, López-Cortés N, Alcaide M, Del Pozo MV, Vieites JM, von Bergen M, Gallego JLR, Bargiela R, López-López A, Pieper DH, Rosselló-Móra R, Sánchez J, Seifert J, Ferrer M (2012) Metaproteogenomic insights beyond bacterial response to naphthalene exposure and bio-stimulation. ISME J doi: 10.1038/ismej.2012.82.

[47] De Corte S, Hennebel T, Fitts JP, Sabbe T, Bliznuk V, Verschuere S, van der Lelie D, Verstraete W, Boon N (2011b). Biosupported bimetallic Pd/Au nanocatalysts for dechlorination of environmental contaminants. Environ Sci Technol 45:8506-8513.

[48] De Corte S, Sabbe T, Hennebel T, Vanhaecke L, De Gusseme B, Verstraete W, Boon N (2012) Doping of biogenic Pd catalysts with $\mathrm{Au}$ enables dechlorination of diclofenac at environmental conditions. Water Res 46:2718-2726. 
Fig 1 A survey on the studies performed on the microbiology of marine sites worldwide indicates that a limited number of studies have been performed on the Southern coasts of the Mediterranean Sea. The figure was prepared using Google Earth and includes studies that were published in 2011-2012. The databases used were SCOPUS, PubMed and WOK.

Fig 2 Schematic overview of the phases and approaches used in the ULIXES project 


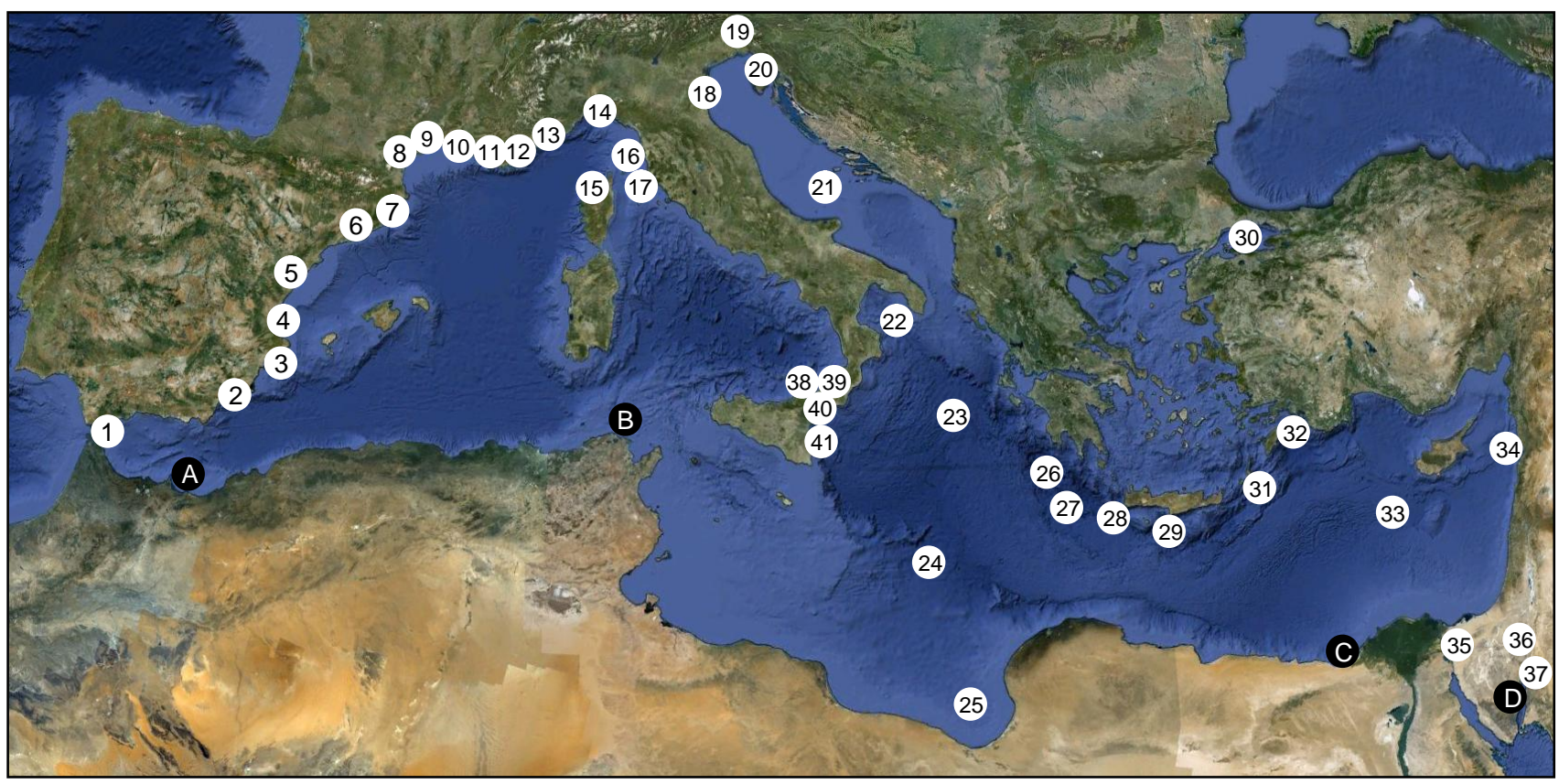

1: Ceuta. Gibraltar Strait. Marine sponges. Ivanisevic et al. (2011).

2: Mazarrón. Marine sponges. Ivanisevic et al. (2011).

3: Mar Menor. Hypersaline-fresh water. Ghai et al. (2012).

4: Santa Pola. Shallow water. Santos et al. (2011).

5: Albufera de Valencia. Hypersaline-fresh water. Ghai et al. (2012).

6: Barcelona. Raw sewage. Cantalupo et al. (2011).

7: Santa Anna. Blannes. Shallow water sponges. Cretoiu et al. (2012).

8: Banyuls-sur-Mer. France. Marine sponges. Bayer et al. (2012).

9: Perpignan. Marine fishes. Ardura et al. (2011).

10: Roussillon. Marine fishes. Ardura et al. (2011).

11: Maire, Jarre and Riou Islands. Marine sponges. Ivanisevic et al. (2011).

12: La Ciotat. Marine sponges. Ivanisevic et al. (2011).

13: Toulon Bay. Shallow water with trace metal. Jean et al. (2012).

14: Port Genoa. Shallow water and sediment. Anthropogenic impact. Kisand et al. (2012).

15: Gulf of Porto. Corsica. France. Marine sponges. Ivanisevic et al. (2011).

16: Elba. Marine sponges. Bayer et al. (2012).

17: Montecristo island. Shallow water and sediment. Kisand et al. (2012).

18: Ravenna. Marine fishes. Picone et al. (2011).

19: Monfalcone. Marine fishes. Picone et al. (2011).

20: Rovinj, Croatia. Marine sponges. Bayer et al. (2012).

21: Adriatic sea. Surface-deep sea water. BrochierArmanet et al. (2011). López-Pérez et al. (2012 a,b).
22: H07. Surface-deep sea water. Hutz et al. (2011).

23: Ionian sea. Deep sea water. Brochier-Armanet et al. (2011).

24: Mediterranean Sea. Shallow water. Thompson et al. (2011).

25: H10. Surface-deep sea water. Hutz et al. (2011).

26: Station Matapan-Vavilov. Surface-deep sea water. Smedile et al. (2013).

27: H02. Surface-deep sea water. Hutz et al. (2011).

28: Urania Basin. Surface waters. López-Pérez et al. (2012b).

29: Lake Thetis. Deep sea. Ferrer et al. (2012).

30: Sea of Marmara. Bottom sediment. Quaiser et al. (2011).

31: ler01. Surface-deep sea water. Hutz et al. (2011).

32: Rho02. Surface-deep sea water. Hutz et al. (2011).

33: Eastern Mediterranean Sea. Shallow water. Zurel et al. (2011).

34: Aegean Sea. Lebanon. Surface waters. López-Pérez et al. (2012b).

35: Suez. Marine sediments from industrial wastes.

Elsaied et al. (2011).

36: Gulf of Eilat. Red Sea. Surface seawater. Wang et al. (2011).

37: Northern Red Sea. Shallow water. Zurel et al. (2011).

38: Messina Harbour. Surface oil polluted seawater. Cappello et al. (2011, 2012 a,b,d).

39: Messina Strait. Hydrocarbon polluted seawater. Gertler et al. (2012).

40: Lake Faro. Mussels. Cappello et al. (2012c).

41: Augusta Harbour. floating tank of an oil costal deposit. Mancini et al. (2012).

A: Mar Chica lagoon,Morocco. Agriculture and industries wastewaters pollution.

B: Bizerte lagoon, Tunisia. Petroleum derivatives pollution.

C: El-Max district, Egypt. Heavy metals, PAHs and crude oil-derived pollution.

D: Aqaba Gulf, Jordan. Oil pollution. 


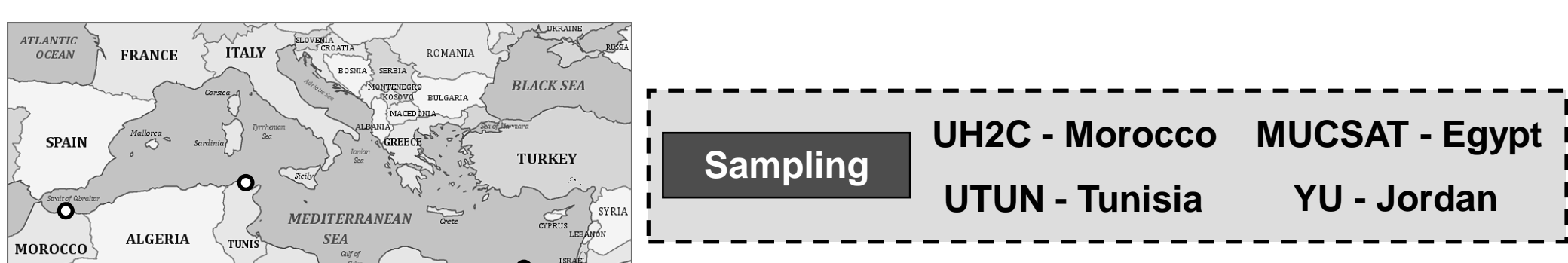

Southern Med polluted sites EGYPT

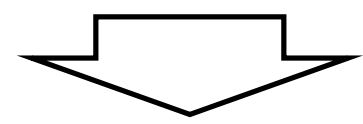

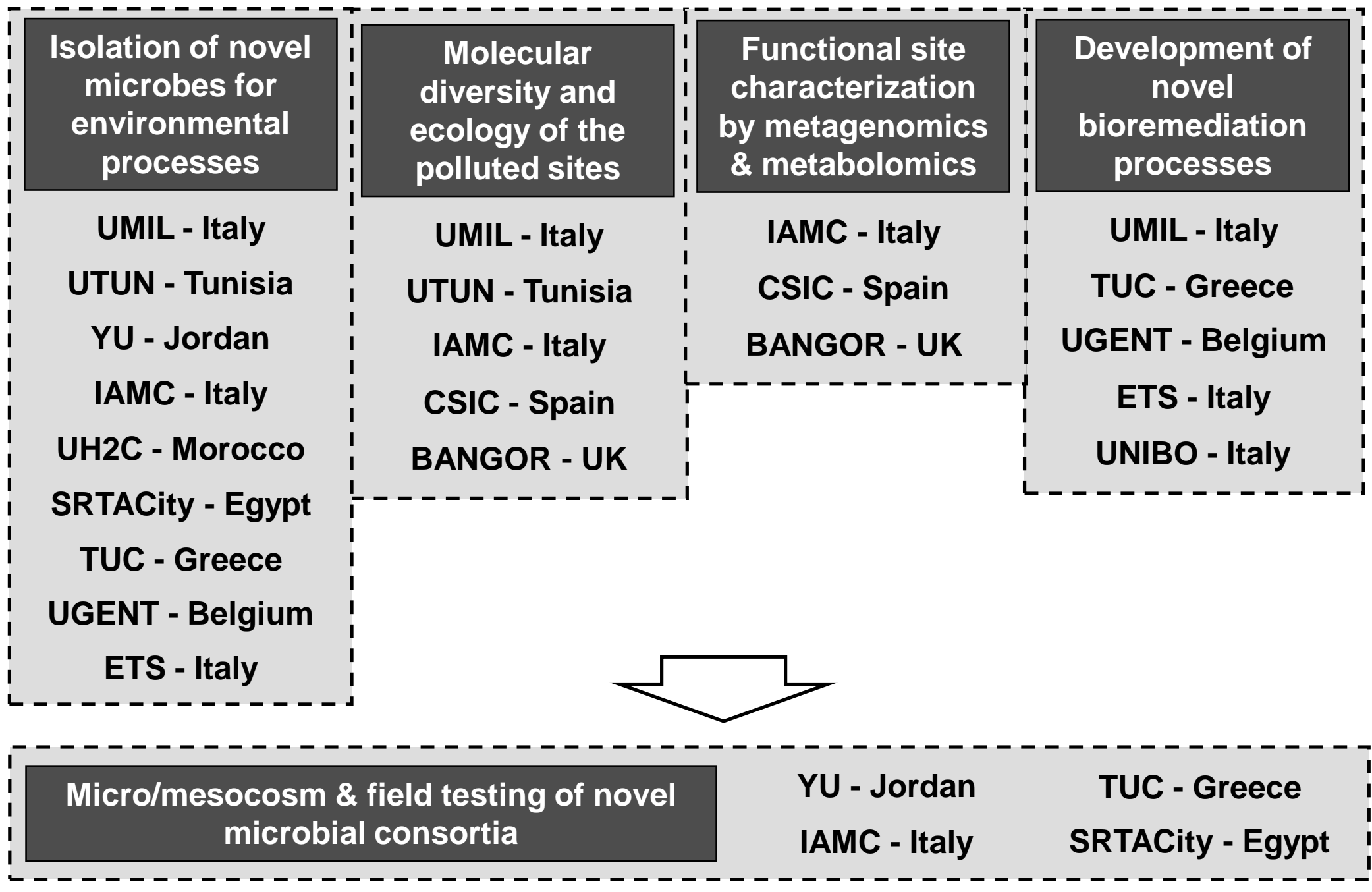

